TẠP CHÍ KHOA HỌC ĐẠI HỌC TÂN TRÀO

ISSN: 2354 - 1431

http://tckh.daihoctantrao.edu.vn/

\title{
TỐI UUU HÓA QUY TRÌNH SẢN XUẤT PHÂN BÓN DẠNG LỎNG TÙ๋ BÃ MEN BIA SỬ DỤNG CHẾ PHẨM ENZYME ALCALASE THƯƠNG MẠI
}

\author{
Đinh Thị Kim Hoa ${ }^{1 *}$, Luu Hồng Sơn ${ }^{l}$, Tạ Thị Lương ${ }^{l, 2}$, Lê Minh Châu ${ }^{l}$, Duoong Ngọc Duoong ${ }^{l}$, Trần Văn Chí ${ }^{l}$, \\ Vi Đại Lâm ${ }^{l}$, Nguyễn Thị Tình ${ }^{l}$, Nguyễn Văn Duy ${ }^{l}, N g \hat{o}$ Xuân Bình ${ }^{l}$ \\ ${ }^{1}$ Truò̀ng Đại học Nông Lâm - Đại học Thái Nguyên \\ ${ }^{2}$ Đại học Queensland \\ *Email: Dinhthikimhoa@tuaf.edu.vn
}

\section{Thông tin bài viết}

Ngày nhận bài:

$11 / 5 / 2020$

Ngày duyệt đăng:

$12 / 8 / 2020$

Tù khóa:

Enzyme Alcalase, phân bón, bã men, tối uu, BoxBehnken

\section{Tóm tắt}

Mục đích của nghiên cứu là khảo sát đơn yếu tố ảnh hưởng của tỷ lệ phối trộn thích hợp giữa enzyme (E) và chế phẩm vi sinh vật có ích $(\mathrm{EM})$, tỉ lệ nước bổ sung, nhiệt độ ủ, thời gian ủ tới quá trình thủy phân bã men bia bằng chế phẩm enzyme alcalase. Các thí nghiệm đơn nhân tố thu được kết quả tỉ lệ enzyme và chế phẩm EM bổ sung là EM $2 \%+\mathrm{E} 1,5 \%$, tỉ lệ nguyên liệu/nước là 1/3, nhiệt độ thủy phân là $45^{\circ} \mathrm{C}$ và thời gian là $8 \mathrm{~h}$ giờ. Trên cơ sở khảo sát từng yếu tố ảnh hưởng đến điều kiện thủy phân, cho thấy các thông số tỷ lệ phối trộn giữa enzyme và $\mathrm{EM}$, tỷ lệ nước bổ sung, nhiệt độ và thời gian thủy phân là những yếu tố ảnh hưởng mạnh đến quá trình thủy phân. Bằng phương pháp quy hoạch thực nghiệm Box- Behnken đã tìm được điều kiện tối ưu quá trình thủy bã men bia là tỷ lệ phối trộn giữa enzyme và EM là $\mathrm{EM} 2 \%+\mathrm{E} 1,5 \%$, tỉ lệ nước bổ sung: $1 / 3$, nhiệt độ thủy phân là $45^{\circ} \mathrm{C}$ và trong thời gian là 8 giờ. Kết quả thực nghiệm cho kết quả có độ tương thích cao với mô hình.

\section{MỞ ĐẦU}

Quá trình sản xuất bia thải ra rất nhiều loại phế liệu: Phế liệu hạt, mầm malt, bã malt, cặn protein, nấm men bia và $\mathrm{CO}_{2}$. Ngoài $\mathrm{CO}_{2}$ là nguồn phế liệu có thể tái sử dụng để tăng chất lượng bia thì bã malt, mầm malt và nấm men bia là nguồn phế liệu có ý nghĩa quan trọng trong thực phẩm và thức ăn gia súc cả về số lượng và giá trị dinh dưỡng. Bã nấm men bia là một phế phẩm của sản xuất, được nằm lại trong các thùng lên men và các hầm chứa sau khi lên men chính và lên men phụ. Men bia có giá trị dinh dưỡng cao và chữa bệnh tốt. Bã men bia (hay còn gọi là nấm men bia) thuộc loài Saccharomyces cerviside, có hoạt tính enzyme invertase (EC 1.2.4). Enzyme này thường tập trung chủ yếu ở trong lớp không gian chứa tế bào nấm men [3], [4]. Ở Việt Nam nói chung và nhà máy sản xuất bia ở Thái Nguyên nới riêng, bã men bia chưa được sử dụng một cách có hiệu quả mà chỉ thải ra môi trường bên ngoài, điều này gây ô nhiễm môi trường vì chất thải men bia có hàm lượng $\mathrm{COD}$ rất cao. Việc đưa ra dạng phân bón dạng lỏng từ thủy phân bã men bia có ý nghĩa rất lớn. Việc thủy phân bã men bia chịu ảnh hưởng bởi tỉ lệ phối trộn $\mathrm{EM}+\mathrm{E}$ thích hợp, tỉ lệ nước bổ sung, nhiệt độ ủ và thời gian thủy phân. Vì vậy mục đích của nghiên cứu là nhằm tối ưu hóa quá trình thủy phân protein hòa tan từ bã men bia tại trường Đại học Nông Lâm Thái Nguyên, tỉnh Thái Nguyên. 


\section{VẬT LIỆU VÀ PHƯƠNG PHÁP NGHIÊN CÚ'U}

\subsection{Vật liệu nghiên cứu}

Bã men bia (hay còn gọi là nấm men bia) thuộc loài Saccharomyces cervisiae, được lấy tại nhà máy bia Vicoba, 158 Minh Cầu, Thành phố Thái Nguyên, tỉnh Thái Nguyên. Nguyên liệu được phân loại sau đó đem đi sấy ở nhiệt độ $80^{\circ} \mathrm{C}$ đến độ ẩm < $10 \%$, tiến hành bảo quản trong túi nhựa polyetylen (PE) đặt trong hộp nhựa kín, lưu trữ ở nhiệt độ phòng, tránh ánh sáng và ẩm.

Dung môi được sử dụng trong nghiên cứu là nước cất (dạng tinh khiết - Việt Nam)

\subsection{Bố trí thí nghiệm}

Protein hòa tan được thủy phân từ bã men bia bằng việc bổ sung nước với tỷ lệ nguyên liệu/nước là $1 / 2$, $1 / 3,1 / 4$; tỉ lệ phối trộn EM và E là $1 \%$ - 1,5\%; 1,5\% $1,5 \% ; 2 \%-1,5 \% ; 1,5 \%$ - 1\%; 1,5\% - 2\%; nhiệt độ ủ lần lượt là $35^{\circ} \mathrm{C}, 45^{\circ} \mathrm{C}, 55^{\circ} \mathrm{C}$; thời gian thủy phân lần lượt là 7 giờ, 8 giờ, 9 giờ. Sau khi tiến hành khảo sát các đơn nhân tố, chúng tôi lựa chọn 3 yếu là các yếu tố ảnh hưởng lớn nhất đến việc thủy phân bã men bia để đánh giá khả năng ảnh hưởng của chúng, chúng tôi sử dụng phương pháp bề mặt chỉ tiêu theo thiết kế thí nghiệm của Box - Behnken với 3 yếu tố, 3 cấp độ.

\section{Xác định hàm lượng protein hòa tan}

Hàm lượng protein hòa tan trong dịch thủy phân được xác định bằng phương pháp Lowry [6]. Phương pháp dựa trên cơ sở phức chất đồng protein khử hỗn hợp photphomolipden - photphovonphramat (thuốc thử Folin - ciocalteu) tạo phức chất màu xanh da trời có độ hấp thụ cực đại ở bước sóng 660nm. Cường độ màu của hỗn hợp phản ứng tỉ lệ thuận với nồng độ protein trong một phạm vi nhất định. Dựa vào mức độ hấp thụ quang học của protein chuẩn, ta có thể xác định được hàm lượng protein trong mẫu nghiên cứu.

\section{Xây dưng đưòng đồ thị chuẩn}

Sử dụng albumin huyết thanh bò (BSA) làm chất chuẩn để xây dựng đường chuẩn thể hiện mối quan hệ giữa độ hấp thụ ánh sáng ở bước sóng $660 \mathrm{~nm}$ và nồng độ protein. Cân 0,01g (10 mg - albumin huyết thanh bò) hoà tan trong $10 \mathrm{ml}$ nước, ta được dung dịch gốc có nồng độ là $1 \mathrm{mg} / \mathrm{ml}$. Sau đó pha loãng dung dịch gốc bằng nước cất với các nồng độ $20,40,60,80,100$, $120 \mu \mathrm{g} / \mathrm{ml}$ để tiến hành xây dựng đồ thị chuẩn. Lấy chính xác $0,5 \mathrm{ml}$ dung dịch BSA ở nồng độ pha loãng như trên cho vào ống nghiệm, thêm vào mỗi ống $2 \mathrm{ml}$ dung dịch $\mathrm{C}$ (là hỗ hợp của Dung dịch $\mathrm{A}: 4 \mathrm{~g} \mathrm{NaOH}$ $(0,1 \mathrm{M})$ và $20 \mathrm{~g} \mathrm{Na}_{2} \mathrm{CO}_{3}(2 \%)$ pha trong $1000 \mathrm{ml}$ nước cất và dung dịch $\mathrm{B}: 0,5 \mathrm{~g} \mathrm{CuSO}_{4} .5 \mathrm{H}_{2} \mathrm{O}(0,5 \%)$ pha trong dung dịch Natri Xitrat (1\%) hoặc trong dung dịch Natri, Kali Tactơrat 1\% theo tỉ lệ theo tỉ lệ 49:1) để ở nhiệt độ phòng 10 phút, sau đó cho $0,25 \mathrm{ml}$ thuốc thử folin $(1 \mathrm{~N})$ đem so mầu với bước sóng 660nm.

Mẫu đối chứng: lấy $0,5 \mathrm{ml}$ nước cất cho vào ống nghiệm, thêm vào đó $2 \mathrm{ml}$ dung dịch $\mathrm{C}$ và các bước tiếp theo được tiến hành như mẫu thí nghiệm.

Qua 3 lần lặp lại thí nghiệm có thể xây dựng đường hồi quy. Kết quả được xử lý theo phương pháp thống kê thông thường. Vẽ đồ thị chuẩn biểu diễn sự phụ thuộc của $\mathrm{OD}$ với hàm lượng protein.

Mẫu thí nghiệm: lấy chính xác $0,5 \mathrm{ml}$ dịch chứa protein với hàm lượng thích hợp cho vào ống nghiệm, thêm vào đó $2 \mathrm{ml}$ dung dịch $\mathrm{C}$, lắc đều để yên trong 10 phút. Sau đó thêm vào hỗn hợp trong ống nghiệm $0,25 \mathrm{ml}$ thuốc thử Folin đã pha loãng 2 lần, lắc đều và để yên trong 30 phút, màu vàng của hỗn hợp chuyển sang màu xanh da trời và đạt đến cường độ màu cực đại. Đem so màu của hỗn hợp trên máy đo quang ở bước sóng $660 \mathrm{~nm}$. Xác định được trị số mật độ quang học (OD) của dung dịch nghiên cứu. Đo trên máy 3 lần lặp lại và lấy trị số trung bình. Dựa vào đồ thị chuẩn, có thể xác định được hàm lượng protein trong mẫu nghiên cứu.

\subsection{Phương pháp xử lý số liệu}

Số liệu sẽ được xử lý, phân tích phương sai 1 nhân tố (One - way ANOVA) dùng phần mềm SPSS 20.0.

\section{KÊT QUẢ VÀ THẢO LUẬN}

\section{1. Ảnh hưởng của tỷ lệ phối trộn giữa $\mathrm{EM}$ và} enzyme

Kết quả nghiên cứu ảnh hưởng của tỉ lệ phối trộn enzyme Alcalase và chế phẩm EM BESTOT N02 tới chất lượng phân bón dạng nước được thể hiện ở bảng 1 . 
Bảng 1. Kết quả nghiên cưu ảnh hưởng của tỉ lệ phối trộn enzyme và EM

\begin{tabular}{|c|c|c|}
\hline $\mathbf{C T}$ & Tỷ lệ phối trộn (\%) & Hàm lượng pro hòa tan $(\mathbf{m g} / \mathbf{m l})$ \\
\hline 1 & $1 \%+1,5 \%$ & $71,55^{\mathrm{a}}$ \\
\hline 2 & $1,5 \%+1,5 \%$ & $77,30^{\mathrm{c}}$ \\
\hline $\mathbf{3}$ & $\mathbf{2 \% + 1 , 5 \%}$ & $\mathbf{8 2 , 1 1 ^ { \mathrm { e } }}$ \\
\hline 4 & $1,5 \%+1 \%$ & $77,41^{\mathrm{d}}$ \\
\hline 3 & $1,5 \%+2 \%$ & $74,41^{\mathrm{b}}$ \\
\hline
\end{tabular}

Ghi chú: Các chũ trong cùng một cột biểu thị sụ sai khác có ý nghĩa thống kê ở mức $\alpha=0,05$

Bảng 1 cho thấy việc phối trộn enzyme và EM ảnh hưởng rõ rệt tới hiệu quả thủy phân bã men bia cũng như tới chỉ tiêu chất rắn hòa tan của quả cây dưa lưới $\mathrm{AB}$. Việc phối trộn hai loại enzyme và EM cho thấy hàm lượng protein hòa tan thu được cao hơn hẳn so với việc dùng từng yếu tố xúc tác đơn lẻ. Ta dễ thấy với CT3 kết quả đạt được vượt trội hơn cả so với bốn công thức còn lại $(81,11 \mathrm{mg} / \mathrm{ml})$. Ngược lại $\mathrm{CT} 1$ cho kết quả thấp nhất trong $5 \mathrm{CT}(71,55 \mathrm{mg} / \mathrm{ml})$. Điều này cho ta thấy tỉ lệ phối trộn chế phẩm EM và enzyme ở
CT3 (EM $2 \%+1,5 \%$ E) là thích hợp nhất so với các công thức phối trộn khác. Từ tất cả những nhận xét trên chúng tôi lựa chọn công thức phối trộn EM $2 \%$ + 1,5\% E để cố định cho các thí nghiệm tiếp theo.

\section{2. Ảnh hưởng của tỉ lệ nước bổ sung}

Sau khi lựa chọn được loại cũng như tỉ lệ sử dụng enzyme và chế phẩm sinh học EM cho mục đích thủy phân bã men bia thành, ta tiến hành nghiên cứu tìm tỉ lệ nước bổ sung thích hợp thông qua hàm lượng protein hòa tan. Kết quả thể hiện ở bảng 2 .

Bảng 2. Kết quả ảnh hưởng của tỉ lệ nước bổ sung.

\begin{tabular}{|c|c|c|}
\hline $\mathbf{C T}$ & Tỉ lệ nước $\mathbf{m}_{\text {bmb }}$ & Hàm lượng pro hòa tan $(\mathbf{m g} / \mathbf{m l})$ \\
\hline 1 & $1: 2$ & $78,87^{\mathrm{b}}$ \\
\hline $\mathbf{2}$ & $\mathbf{1 : 3}$ & $\mathbf{8 2 , 5 9}^{\mathbf{c}}$ \\
\hline 3 & $1: 4$ & $77,22^{\mathrm{a}}$ \\
\hline
\end{tabular}

Ghi chú: Các chũ trong cùng một cột biểu thị sụ sai khác có ý nghĩa thông kê ở mức $\alpha=0,05$

Dựa vào kết quả ở bảng 2 , khi thay đổi tỉ lệ nước bổ sung thì hiệu quả thủy phân của enzyme và chế phẩm EM cũng thay đổi và đều khác nhau giữa cả 3 công thức nghiên cứu. Hàm lượng protein hòa tan thu được cao nhất ở $\mathrm{CT} 2$ là $82,59(\mathrm{mg} / \mathrm{ml})$ và thấp nhất với CT3 là 77,22 (mg/ml). Từ kết quả nghiên cứu trên, ta lựa chọn CT2, với tỉ lệ bổ sung nguyên liệu/nước là $1 / 3$ để xây dựng quy trình sản xuất phân bón dạng nước từ nguồn nguyên liệu bã men bia.

\section{3. Ảnh hưởng của thời gian ủ}

Bã men bia được tiến hành thủy phân với các thông số về tỉ lệ phối trộn enzyme và EM, tỉ lệ nước bổ sung đã được tối ưu ở các thí nghiệm 1 và 2 trong các khoảng thời gian $7 \mathrm{~h}, 8 \mathrm{~h}, 9 \mathrm{~h}$. Sau đó tiến hành phân tích hàm lượng protein hòa tan. Kết quả thu được thể hiện ở bảng 3 .

Bảng 3. Kết quả nghiên cứu ảnh hưởng của thời gian ủ

\begin{tabular}{|c|c|c|}
\hline CT & Thời gian (giờ) & Hàm lượng pro hòa tan $(\mathbf{m g} / \mathbf{m l})$ \\
\hline 1 & 7 & $79,17^{\mathrm{a}}$ \\
\hline $\mathbf{2}$ & $\mathbf{8}$ & $\mathbf{8 3 , 4 1}^{\mathbf{b}}$ \\
\hline 3 & 9 & $83,09^{\mathrm{b}}$ \\
\hline
\end{tabular}

Ghi chú: Các chĩ trong cùng một cột biểu thị sụ sai khác có ý nghĩa thống kê ở mức $\alpha=0,05$

Qua bảng 3, thời gian thủy phân có ảnh hưởng tới hàm lượng protein hòa tan. Nhìn chung khi tăng thời gian thủy phân, hàm lượng protein hòa tan thu được tăng. Hàm lượng protein hòa tan thu được ở $\mathrm{CT} 2$ và 
CT3 cao hơn so với $\mathrm{CT} 1$, nhưng giữa $\mathrm{CT} 2$ và $\mathrm{CT} 3$ lại không có sự khác biệt ở mức ý nghĩa $\alpha=0,05$, mặc dù $\mathrm{CT} 2$ thời gian thủy phân dài hơn $\mathrm{CT} 3$ là 1 giờ. Điều này có thể giải thích là do trong thời gian 8 giờ lượng cơ chất đã được enzyme thủy phân triệt để. Từ nhận xét trên, để giảm thời gian sản xuất, tiết kiệm được chi phí, ta lựa chọn thời gian thủy phân bã men bia để sản xuất phân bón dạng nước là 8 giờ.

\section{4. Ảnh hưởng của nhiệt độ}

Để xác định được nhiệt độ ủ chế phẩm EM và thủy phân bã men bia phù hợp, tiến hành thủy phân nguyên liệu trong điều kiện cố định các yếu tố công nghệ đã xác định được ở các thí nghiệm 1,2 và 3 trong các nhiệt độ khác nhau lần lượt là: $35^{\circ} \mathrm{C}, 45^{\circ} \mathrm{C}, 55^{\circ} \mathrm{C}$. Sau $8 \mathrm{~h}$ tiến hành đo hàm lượng protein hòa tan, thu được kết quả thể hiện ở bảng 4.

Bảng 4. Kết quả nghiên cứu ảnh hưởng của nhiệt độ

\begin{tabular}{|c|c|c|}
\hline CT & Thời gian (giò̀) & Hàm lượng pro hòa tan $(\mathbf{m g} / \mathbf{m l})$ \\
\hline 1 & 35 & $79,47^{\mathrm{a}}$ \\
\hline $\mathbf{2}$ & $\mathbf{4 5}$ & $\mathbf{8 3 , 4 6}^{\mathbf{b}}$ \\
\hline 3 & 55 & $83,23^{\mathrm{b}}$ \\
\hline
\end{tabular}

Ghi chú: Các chũ trong cùng một cột biểu thị sụ sai khác có ý nghĩa thống kê ở mức $\alpha=0,05$

Dựa vào kết quả bảng 4 ta thấy nhiệt độ cũng là một yếu tố ảnh hưởng tới hiệu quả thủy phân của enzyme và EM. Khi tăng nhiệt độ thủy phân từ $35^{\circ} \mathrm{C}$ tới $45^{\circ} \mathrm{C}$ thì hàm lượng protein hòa tan thu được tăng, tuy nhiên nếu tiếp tục tăng nhiệt độ lên tới $55^{\circ} \mathrm{C}$ thì hàm lượng protein hòa tan thu được thay đổi không đáng kể, không có sự sai khác biệt với công thức ở nhiệt độ $55^{\circ} \mathrm{C}$, hàm lượng protein hòa tan thu được nằm ở khoảng $83 \mathrm{mg} / \mathrm{ml}$. Điều này có thể cho ta thấy, nhiệt độ tối ưu cho sự thủy phân của enzyme Alcalase nằm trong khoảng $45^{\circ} \mathrm{C}$, kết quả này cũng phù hợp với nghiên cứu của tác giả Normah I. và cộng sự công bố năm 2005 [5]. Từ kết quả trên, chúng tôi lựa chọn nhiệt độ tối ưu cho quá trình thủy phân phân bón dạng nước từ nguồn nguyên liệu bã men bia là $45^{\circ} \mathrm{C}$.

\subsection{Tối ưu hóa quá trình thủy phân}

Chúng tôi sử dụng phương pháp bề mặt chỉ tiêu theo thiết kế thí nghiệm của Box- Behnken với ba biến ba cấp độ. Các số liệu thu được từ dịch thủy phân bã men bia được xử lý trên phần mềm Design- Expert 7.0 (Stat-Ease Inc, Minneapolis, USA) ANOVA được dùng để đánh giá kết quả thu được. Tiến hành giải bài toán tối ưu theo phương pháp "hàm mong đợi". Sử dụng phần mềm Design-Expert 7.0 để tiến hành tối ưu hóa nhằm xác định được giá trị của ba yếu tố mà tại đó hàm lượng protein hòa tan là cao nhất [5]. Áp dụng phương pháp phân tích hồi quy các số liệu thực nghiệm, thu được mô hình đa thức bậc hai thể hiện hàm lượng protein hòa tan:

$$
Y=+83.44+0.15 * A+0.38 * B+0.74 * C-1.08 * A * B-0.20 * A * C-0.30 * B * C-3.26 * A^{2}-1.67 B^{2}-0.85 * C^{2}
$$

Trong đó $\mathbf{Y}$ là hàm lượng protein hòa tan trong dịch thủy phân thu được.

Bảng 5. Ma trận thục nghiệm Box-Behken ba yếu tố thủy phân bã men bia

\begin{tabular}{|c|c|c|c|c|}
\hline \multirow{2}{*}{ TN } & \multicolumn{3}{|c|}{ Biến thực } & $\begin{array}{c}\text { Hàm lượng pro } \\
\text { hòa tan } \\
\text { (mg/ml) }\end{array}$ \\
\cline { 2 - 5 } & $\begin{array}{c}\mathbf{A} \\
\text { (Tỷ lệ nước bổ sung) }\end{array}$ & $\begin{array}{c}\text { B } \\
\text { (nhiệt độ) }\end{array}$ & $\begin{array}{c}\text { C } \\
\text { (thò̀i gian) }\end{array}$ & 77,64 \\
\hline 1 & 2 & 35 & 8 & 79,17 \\
\hline 2 & 4 & 35 & 8 & 80,02 \\
\hline 3 & 2 & 55 & 8 & 77,22 \\
\hline 4 & 4 & 55 & 8 & 77,83 \\
\hline 5 & 2 & 45 & 7 & 79,47 \\
\hline 6 & 4 & 45 & 7 & 79,59 \\
\hline 7 & 2 & 45 & 9 & 80,45 \\
\hline 8 & 4 & 45 & 9 & 79,17 \\
\hline 9 & 3 & 35 & 7 & 81,09 \\
\hline 10 & 3 & 55 & 7 & 81,36 \\
\hline 11 & 3 & 35 & 9 & \\
\hline
\end{tabular}


D.T.K.Hoa et al/No.17_Aug 2020|p.54-60

\begin{tabular}{|c|c|c|c|c|}
\hline \multirow[b]{2}{*}{ TN } & \multicolumn{3}{|c|}{ Biến thưc } & \multirow{2}{*}{$\begin{array}{c}\text { Hàm lượng pro } \\
\text { hòa tan } \\
(\mathrm{mg} / \mathrm{ml})\end{array}$} \\
\hline & $\begin{array}{c}\text { A } \\
\text { (Tỷ lệ nước bổ sung) }\end{array}$ & $\begin{array}{c}\text { B } \\
\text { (nhiệt độ) }\end{array}$ & $\begin{array}{c}\mathrm{C} \\
\text { (thò̀i gian) }\end{array}$ & \\
\hline 12 & 3 & 55 & 9 & 82,18 \\
\hline 13 & 3 & 45 & 8 & 83,35 \\
\hline 14 & 3 & 45 & 8 & 83,47 \\
\hline 15 & 3 & 45 & 8 & 83,45 \\
\hline 16 & 3 & 45 & 8 & 83,46 \\
\hline 17 & 3 & 45 & 8 & 83,45 \\
\hline
\end{tabular}

Để đánh giá mô hình chúng tôi sử dụng phân tích ANOVA. Kết quả phân tích ANOVA được thể hiện qua bảng sau:

Bảng 6. Phân tích phuoong sai ANOVA của mô hình thủy phân bã men bia.

\begin{tabular}{|c|c|c|c|c|c|}
\hline Nguồn & SS & DF & MS & Chuẩn F & Giá trị p \\
\hline Model & 75,18 & 9 & 8,35 & 24,28 & 0,0002 \\
\hline A & 0,19 & 1 & 0,19 & 0,55 & 0,4825 \\
\hline B & 1,16 & 1 & 1,16 & 3,38 & 0,1086 \\
\hline C & 4,35 & 1 & 4,35 & 12,65 & 0,0093 \\
\hline AB & 4,69 & 1 & 4,69 & 13,63 & 0,0077 \\
\hline AC & 0,15 & 1 & 0,15 & 0,44 & 0,5274 \\
\hline BC & 0,37 & 1 & 0,37 & 1,08 & 0,3329 \\
\hline$A^{2}$ & 44,62 & 1 & 44,62 & 129,71 & $<0,0001$ \\
\hline B & 11,75 & 1 & 11,75 & 34,15 & 0,0006 \\
\hline$C^{2}$ & 3,03 & 1 & 3,03 & 8,80 & 0,0209 \\
\hline Residual & 2,41 & 7 & 0,34 & & 0,0591 \\
\hline Lack of Fit & 2,40 & 3 & 0,80 & 330,33 & \\
\hline Sai số & $9.680 \mathrm{E}-003$ & 4 & $2.420 \mathrm{E}-003$ & & \\
\hline SS tổng số & 77,69 & 16 & & & \\
\hline
\end{tabular}

SS: Tống phuơng sai; DF:Bậc tư do; MS: Trung bình phuơng sai; Chuẩn F: Chuẩn Fisher; Residual: Phần du;

"Lack of Fit": Chuẩn đánh giá độ không tuoong thích của mô hình với thực nghiệm.

Từ kết quả phân tích ANOVA ta thấy giá trị xác suất của mô hình $\mathrm{P}$-value $=0,0002<0,05$ do đó mô hình được lựa chọn để giải thích cho kết quả của thí nghiệm, Lack of fit test có ý nghĩa đối với mô hình. 


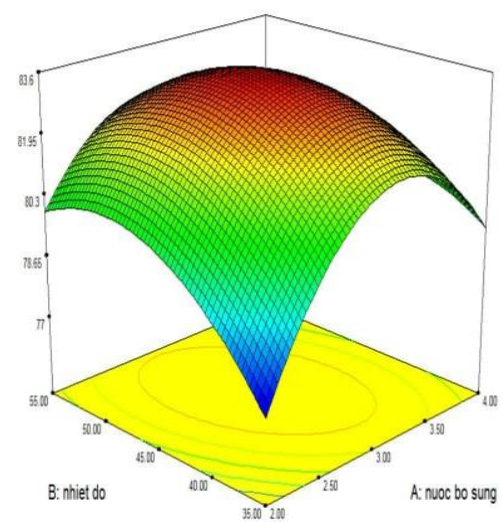

(a)

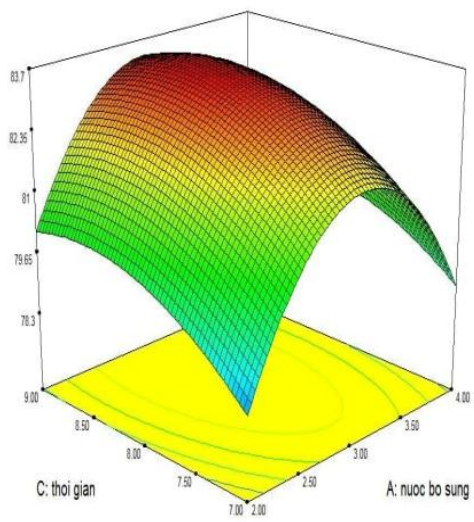

(b)

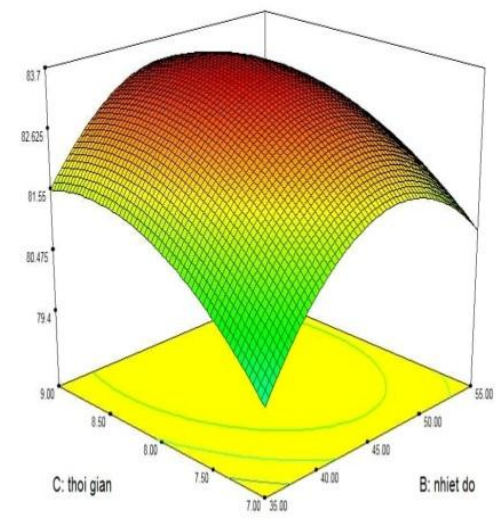

(c)

Hình 1. Bề mặt đáp ứng hàm lượng protein hòa tan.

a) Mô hình tuoong tác giũa tỷ lệ nước bổ sung và nhiệt độ.

b) Mô hình tương tác giữa tỷ lệ nước bổ sung và thòi gian.

c) Mô hình tưong tác giũa nhiệt độ và thời gian.

Phương án tốt nhất được dự đoán tỷ lệ nước bổ Kết quả kiểm tra bằng thực nghiệm cho kết quả sung là 3 , nhiệt độ là $45,40^{\circ} \mathrm{C}$, thời gian là 8,14 giờ tương ứng.

khi đó hàm lượng protein hòa tan đạt $83,5347 \mathrm{mg} / \mathrm{ml}$.

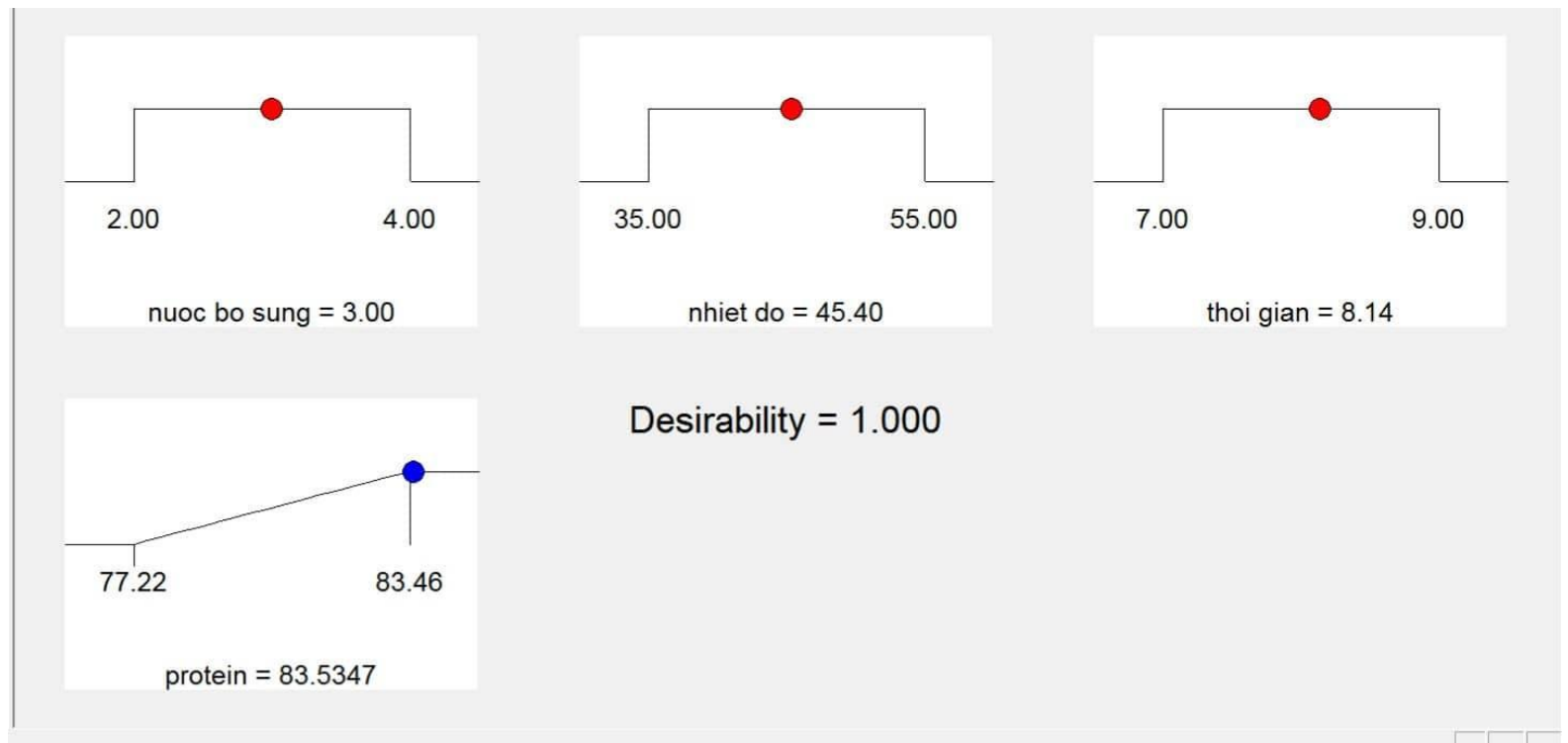

Hình 2. Hàm kỳ vọng và điều kiện tối ưu ở hàm lựng protein hòa tan

\section{Kết luận}

Điều kiện thủy phân để thu hàm lượng protein hòa tan được xác định như sau: Nhiệt độ ủ là $45^{\circ} \mathrm{C}$, tỷ lệ nguyên liệu và nước bổ sung là 3 , thời gian thủy phân là 8 giờ. Chúng tôi sử dụng phương pháp bề mặt chỉ tiêu theo thiết kế thí nghiệm của Box- Behnken với ba biến ba cấp độ cho phương án tốt nhất được dự đoán nhiệt độ ủ $45,40^{\circ} \mathrm{C}$, tỷ lệ nước bổ sung là 3 , thời gian thủy phân là 8,14 giờ. Khi đó hàm lượng protein hòa tan đạt $83,5347 \mathrm{mg} / \mathrm{ml}$. Kết quả kiểm tra bằng thực nghiệm có độ tương thích cao. Kết quả của chúng tôi chỉ ra tiềm năng sử dụng bã men bia trong sản xuất phân bón dạng lỏng trong nông nghiệp.

\section{TÀI LIỆU THAM KHẢO}

1. Nguyen Trong Can (1998), Enzym technology, Publisher: Agricultural Ho Chi Minh city.

2. Nguyen Huu Chan (1996), Enzymes and biological catalysts. Publisher:medicine, Hanoi

3. Hoang Dinh Hoa (2002), Technology for malt and beer production. Publisher: Science and Technology, Hanoi

4. Ketnawa S., Chaiwut, P., Rawdkuen, Extraction of bromelain from pineapple peels, Food 
5. Science and Technology International 17 (4) (2011) 395-402.

6. Normah I., Normah I., Jamilah B., Saari N., and Yaakob B (2005), Optimization of hydrolysis conditions for the production of threadfin bream
(Nemipterus japonicus) hydrolysate by Alcalase, Journal of Muscle Foods 16, 2 (2005) 87.

7. Lowry, O. H., Rosebrough, N. J., Farr, A. L., and Randall, R. J. (1951) Protein measurement with the Folin phenol reagent. J. Biol. Chem. 193, 265-275.

\section{Optimization of the production process of liquid fertilizer}

\section{from beer fermentation residue by using commercial alcalase enzyme}

Dinh Thi Kim Hoa, Luu Hong Son, Ta Thi Luong, Le Minh Chau, Duong Ngoc Duong, Tran Van Chi, Vi Dai Lam, Nguyen Thi Tinh, Nguyen Van Duy, Ngo Xuan Binh

\section{Article info}

Recieved:

$11 / 5 / 2020$

Accepted:

$12 / 8 / 2020$

Keywords:

Enzyme Alcalase,

fertilizer, yeast residue, optimization, Box-

Behnken

\section{Abstract}

The aim of the research is to investigate factors that affect the hydrolysis of beer fermentation residues by using commercial alcalase enzyme. These factors are the appropriate mixture ratio between enzyme and Effective Microorganisms (EM), the ratio of supplemental water, the temperature and the time of the incubation process. The single-factor experiments revealed that the amount of soluble protein achived was highest when these factors were EM $2 \%+\mathrm{E} 1.5 \%, 1 / 3,45^{\circ} \mathrm{C}, 8$ hours correspondingly. On the basis of investigating each factor affecting the hydrolysis conditions, that the study showed that the mixture ratio of enzymes and EM, the ratio of supplemental water, the incubation temperature, and the hydrolysis time were strongly influencing factors to the hydrolysis process. By applying Box- Behnken experiment design model, the optimal condition for the hydrolysis process of beer fermentation residues was found, of which the mixture ratio of enzyme and EM was $\mathrm{EM} 2 \%+\mathrm{E} 1.5 \%$, the ratio of supplemental water was $1 / 3$, the incubation temperature was $45^{\circ} \mathrm{C}$ and the incubation time was 8 hours. 